\title{
Respiratory Effects of TRH in Preterm Rabbits
}

\author{
T. HEDNER, ${ }^{(27)}$ J. HEDNER, J. JONASON, AND D. LUNDBERG \\ Departments of Clinical Pharmacology, Pharmacology and Anesthesiology, University of Göteborg and Sahlgren's \\ Hospital, Göteborg, Sweden
}

\begin{abstract}
Summary
The respiratory activity in newborn preterm (29 days gestation) rabbits was studied after administration of thyrotropic releasing hormone. Intraperitoneal injection induced an increase in respiratory frequency $(f)$ and a decrease in tidal volume $\left(V_{\Upsilon}\right)$ resulting in a slight increase in pulmonary ventilation $\left(\dot{V}_{E}\right)$. These effects were seen in parallel to a decrease in expiratory time $\left(T_{E}\right)$ and respiratory time $\left(T_{T O T}\right)$. An increase in the $T_{I} / T_{\text {TOT }}$ ratio but (unaffected) $V_{T} / T_{I}$ ratio indicates that thyrotropic releasing hormone affects "respiratory timing" mechanisms rather than "inspiratory drive." The changes in respiratory parameters are most probably due to an effect on the central respiratory controlling centers in the brain stem.
\end{abstract}

\section{Speculation}

The increased respiratory activity seen after administration of thyrotropic releasing hormone indicates that this tripeptide may have favourable effects in conditions accompanied by irregular or apnoic breathing during the perinatal period.

The basic rhythmic generator which controls respiratory frequency is located in the lower brain stem region (1). Traditionally, the major part of the work on central respiratory regulation has emphasized the location, connections and electrical properties of the cell groups in the lower part of the brain whose activity is altered in relation to the respiratory cycle. Little attention has previously been focused on the neurochemical mechanisms that are relevant to central respiratory control. However, such studies could provide a basis for the understanding and perhaps also the therapy of various disorders related to respiratory regulation. One such area could be neonatal irregular or apnoic breathing, where respiratory neuronal activity may malfunction due to immaturity or an imbalance between the development of respiratory stimulating and depressive neuronal systems.

Recently, we have demonstrated that various systems such as monoaminergic $(18,19)$, gabaergic $(9,10)$ and various peptidergic $(11,12,13)$ neurons are involved in the regulation of central respiratory activity in adult and newborn animals. In these studies, we have found that intracerebroventricular administration of thyrotropic releasing hormone (TRH) markedly stimulated respiratory frequency in adult rats (11). This finding prompted us to further investigate the effects of systemic administration of TRH to preterm newborn rabbits.

\section{MATERIALS AND METHODS}

Preterm rabbits of Danish rural breed, weighing approximately $45 \mathrm{~g}$, were used in the experiments. The rabbit fetuses were delivered at 29 days of gestation (term being 31 days) by cesarian section under general ether anaesthesia. After delivery the fetuses were immediately transferred to a couveuse (Aga MDOR-10, Sweden) and kept at $28-29^{\circ} \mathrm{C}$ until the initiation of the experiments. All experiments were performed within $6 \mathrm{~h}$ after birth.
After an initial adaptation period in the couveuse of at least $1 \mathrm{~h}$, the rabbit neonates were lightly anaesthetized with ether to permit cannulation of the trachea (Venflon cannula, Viggo AB, Sweden) and the peritoneal cavity (PP50, polyethylene, Portex Ltd, England). After the operative procedures and recovery from the ether

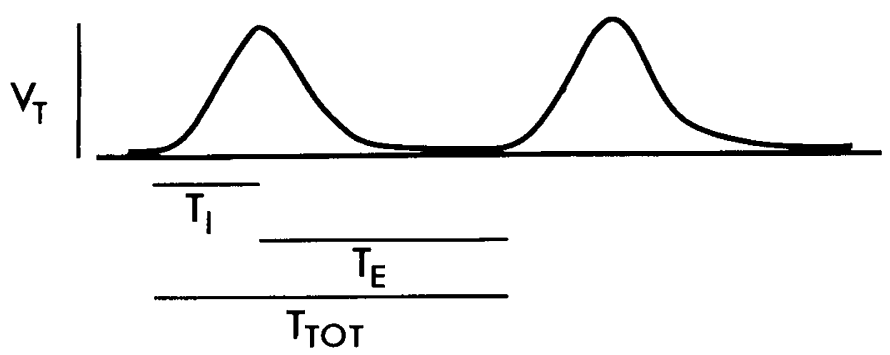

Fig. 1. Replica of original respiratory curve from a 29-day-old preterm rabbit neonate showing tidal volume $\left(\mathrm{V}_{\mathrm{T}}\right)$, inspiratory time $\left(\mathrm{T}_{\mathrm{I}}\right)$, expiratory time $\left(\mathrm{T}_{\mathrm{E}}\right)$ and respiratory time $\left(\mathrm{T}_{\mathrm{TOT}}\right)$.

CONTROL ( saline )

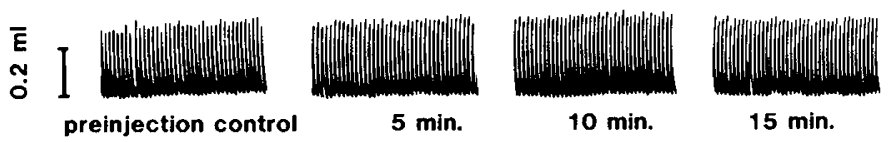

TRH $0.5 \mathrm{mg} / \mathrm{kg}$

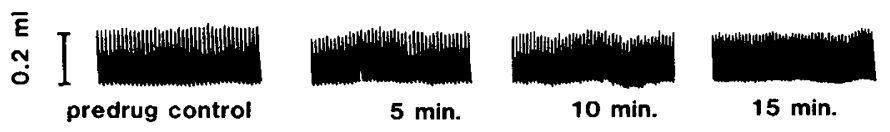

TRH $5 \mathrm{mg} / \mathrm{kg}$

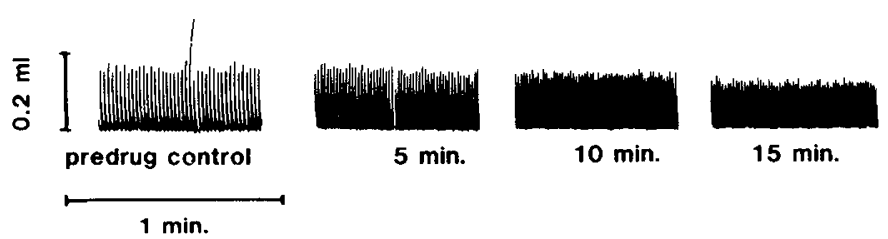

Fig. 2. Replicas of original respiratory recordings in saline and TRH injected preterm neonatal rabbits (gestational age 29 days, term being 31 days). Inspiration upwards.

anaesthesia, the rabbit neonates were placed in a body plethysmograph (a glass fiber tube with internal diameter $8 \mathrm{~cm}$ and length $30 \mathrm{~cm}$ ) with inlet and outlet holes at the ends for the tracheal tube, peritoneal catheter and volume recorder. The volume changes in the body plethysmograph were recorded with a 

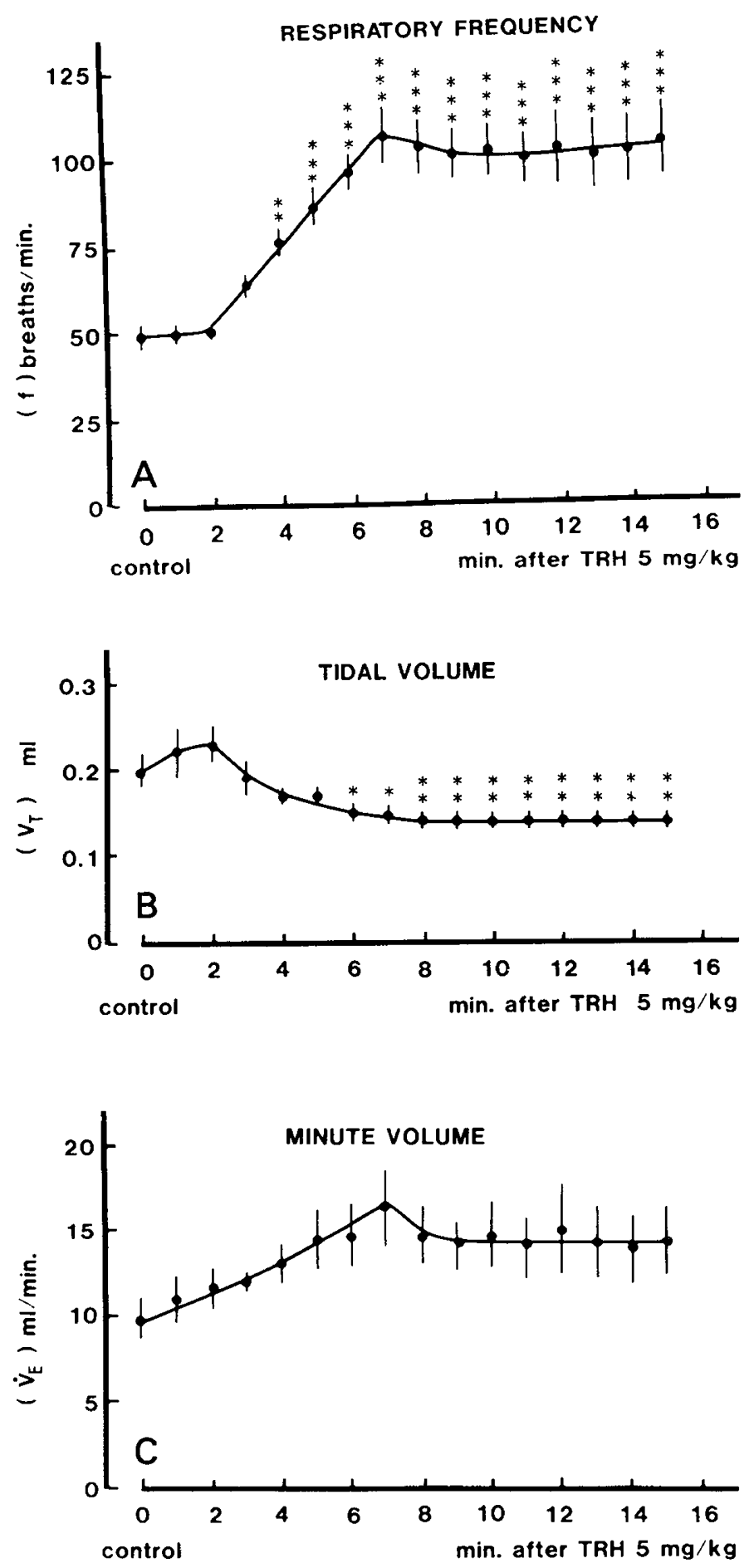

Fig. 3. Effects of TRH on respiratory frequency (f), tidal volume $\left(\mathrm{V}_{\mathrm{T}}\right)$ and minute volume $\left(\dot{\mathrm{V}}_{\mathrm{E}}\right)$. TRH was given intraperitoneally, $5 \mathrm{mg} / \mathrm{kg}$. Shown are means $\pm \mathrm{S}$.E. of respiratory recordings from six preterm rabbit neonates. ${ }^{*} P<0.05,{ }^{* *} P<0.01$, and ${ }^{* * *} P<0.001$.

low pressure transducer (Grass Instrument $\mathrm{Co}$, PT-5A) connected to a model 5 Grass polygraph. During the experiments the rabbit neonates were allowed to breathe $0.7 \%$ halothane in $100 \% \mathrm{O}_{2}$ by means of a Draeger vaporizer. The internal temperature in the body plethysmograph was controlled and adjusted to $28-29^{\circ} \mathrm{C}$. Tidal volume $\left(\mathrm{V}_{\mathrm{T}}\right)$ and respiratory frequency (f) were recorded before (controls) and after drug administration. Minute volume $\left(\dot{\mathrm{V}}_{\mathrm{E}}\right)$ was calculated according to the formula $\mathrm{V}_{\mathrm{T}} \times \mathrm{f}=\dot{\mathrm{V}}_{\mathrm{E}}$. Respiratory time $\left(\mathrm{T}_{\mathrm{TOT}}\right)$, inspiratory time $\left(\mathrm{T}_{\mathrm{I}}\right)$ and expiratory time $\left(T_{E}\right)$ were calculated from the respiratory curve at low chart speed according to Figure 1. In order to get an estimate for "inspiratory
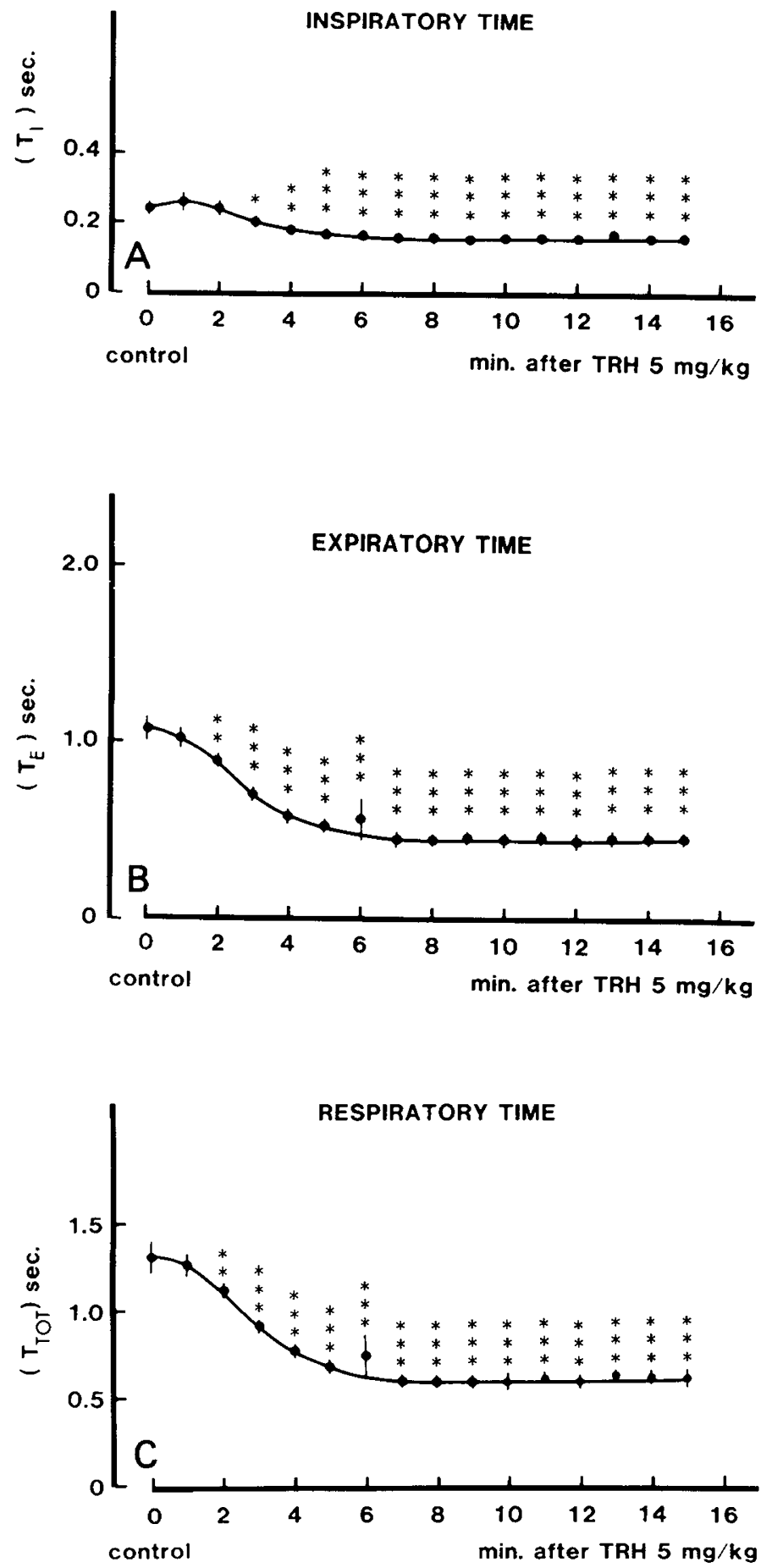

Fig. 4. Effects of $T R H$ on inspiratory $\left(T_{I}\right)$, expiratory $\left(T_{E}\right)$ and respiratory $\left(\mathrm{T}_{\text {TOT }}\right.$ ) time. TRH was given intraperitoneally, $5 \mathrm{mg} / \mathrm{kg}$. Shown are means \pm S.E. of respiratory recordings from six preterm rabbit neonates. ${ }^{*} P<0.05,{ }^{* *} P<0.01,{ }^{* * *} P<0.001$.

drive" and "respiratory timing," $V_{T} / T_{I}$ and $T_{I} / T_{T O T}$, respectively, were calculated.

Experiments were started after a minimum stabilization period in the body plethysmograph of $10 \mathrm{~min}$. After the control recordings and a $10 \% \mathrm{CO}_{2}$ challenge, TRH (Bachem Feinchem. AG) 0.5-10 $\mathrm{mg} / \mathrm{kg}$ was injected via the intraperitoneal catheter. The respiratory variables were then followed for $15 \mathrm{~min}$ and a new $10 \% \mathrm{CO}_{2}$ challenge was performed at the end of the experiment. In some animals saline was given in an equal volume $(1 \mathrm{ml} / 100 \mathrm{~g})$ in order to obtain control recordings for the whole experimental interval studied (Fig. 2).

Statistics were carried out by a two way analysis of variance 

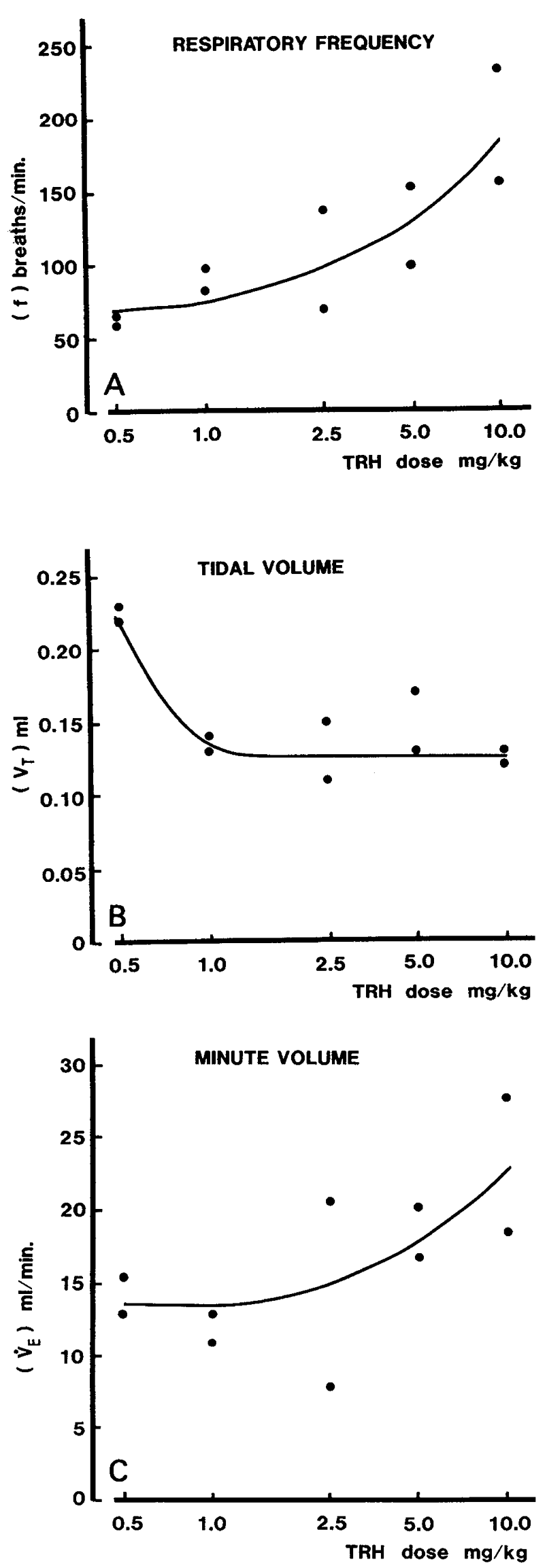

Fig. 5. Dose response curves for respiratory frequency (f), tidal volume $\left(\mathrm{V}_{\mathrm{T}}\right)$ and minute volume $\left(\dot{\mathrm{V}}_{\mathrm{E}}\right) 15$ min after TRH administration intraperitoneally to preterm rabbit neonates (gestational age 29 days).
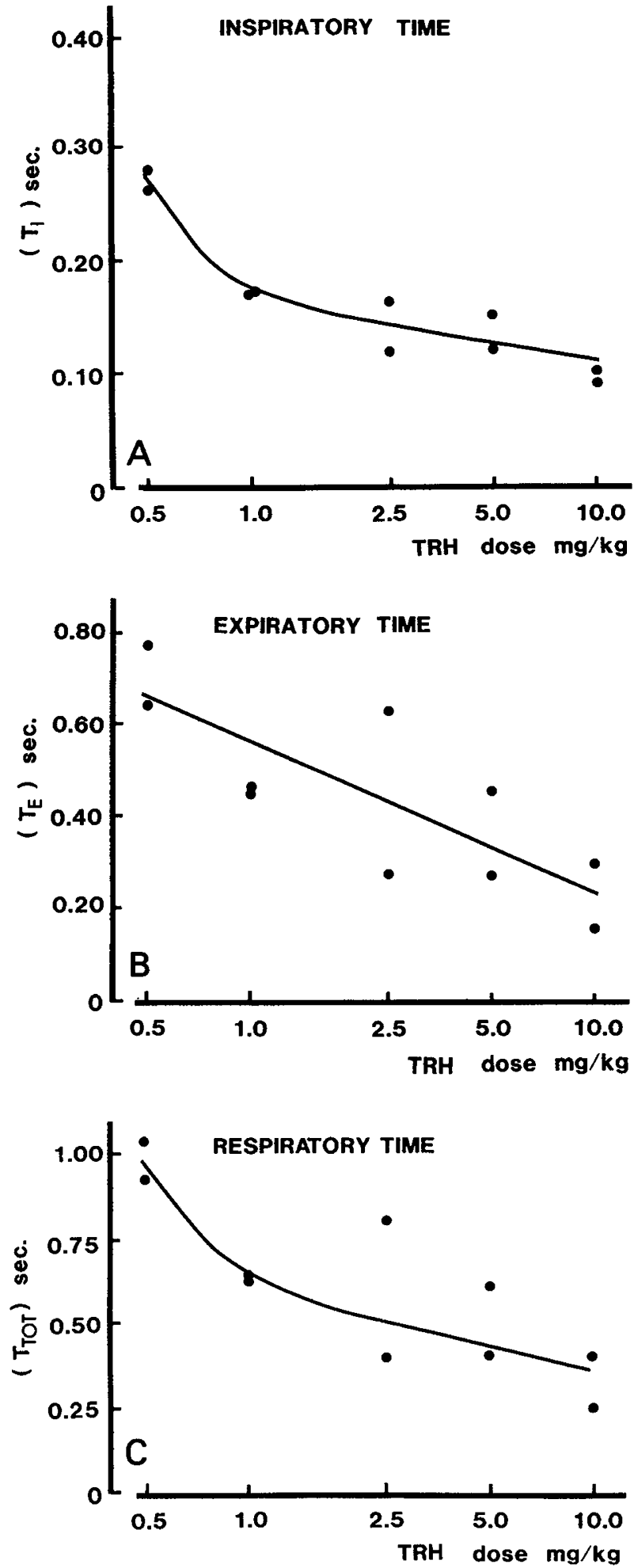

Fig. 6. Dose response curves for inspiratory time $\left(T_{I}\right)$, expiratory time ( $\left.T_{E}\right)$ and respiratory time $\left(T_{T O T}\right) 15 \mathrm{~min}$ after TRH administration intraperitoneally to preterm rabbit neonates (gestational age 29 days).

followed by $t$ test or by paired $t$ test. $P$ values of 0.05 or less were considered significant.

\section{RESULTS}

Records of $V_{\Upsilon}$ and $f$ in preterm rabbit neonates after saline and TRH injection are shown in Figure 2. Following TRH, $5 \mathrm{mg} / \mathrm{kg}$, there was a marked increase in f accompanied by a slight decrease in $V_{T}$ (Fig. 2 and 3). The increase in foccurred rapidly and was 
seen already $4 \mathrm{~min}$ after injection. After a further $5 \mathrm{~min}$ period the increased $f$ stabilized at a level approximately twice the control value. The changes in VzT were less marked and occurred at corresponding intervals after TRH injection as the stimulation of $f$ (Fig. 3). The classical product of $f$ and $V_{T}$, the pulmonary ventilation $\left(\dot{\mathrm{V}}_{\mathrm{E}}\right)$, was slightly increased after TRH injection (Fig. 3). After $7 \mathrm{~min}, \dot{\mathrm{V}}_{\mathrm{E}}$ was approximately $50 \%$ increased compared to the preinjection value (16.24 \pm 2.28 versus $9.73 \pm 1.27 ; n=6$; $P<0.05$ paired $t$ test). As for $f$ and $\mathrm{V}_{\mathrm{T}}$, the increase in $\dot{\mathrm{V}}_{\mathrm{E}}$ was stable after $10 \mathrm{~min}$ of observation and forwards.

During the interval studied $(15 \mathrm{~min})$ there was no attenuation of the effects of TRH on $f, V_{T}$ or $\dot{V}_{E}$.

The respiratory time intervals all decreased in parallel to the increase in $f$. $T_{E}$ and $T_{\text {TOT }}$ were most markedly declined (Fig. 4), generally to about half of its original values. On the contrary there was only a slighter decline in $\mathrm{T}_{\mathrm{I}}$ (Fig. 4).

In the dose-response study performed, $0.5-10 \mathrm{mg} / \mathrm{kg} \mathrm{TRH}$ was given. Both $\mathrm{f}$ and $\dot{\mathrm{V}}_{\mathrm{E}}$ increased while $\mathrm{V}_{\mathrm{T}}$ decreased in a doserelated way (Fig. 5). The respiratory time intervals, $T_{I}, T_{E}$ and $\mathrm{T}_{\text {TOT, }}$, decreased with increasing doses of TRH (Fig. 6).

The mean inspiratory flow $\left(\mathrm{V}_{\mathrm{T}} / \mathrm{T}_{\mathrm{I}}\right)$ was calculated before and after TRH administration (Fig. 7). This is a parameter related to inspiratory neural drive (7). After TRH, $5 \mathrm{mg} / \mathrm{kg}$, there was no significant difference in $V_{T} / T_{I}$ compared to the control registration. The $T_{I} / T_{\text {TOT }}$ ratio is a factor which indicates how "respiratory timing" affects the respiration (7). A change in pulmonary ventilation can be due to a change in $V_{T} / T_{I}$ or $T_{I} / T_{T O T}$ as pulmonary ventilation is related to the mean inspiratory flow and "respiratory timing" according to the formula $\dot{\mathrm{V}}_{\mathrm{E}}=\left(\mathrm{V}_{\mathrm{T}} / \mathrm{T}_{\mathrm{I}}\right) \times$ ( $\mathrm{T}_{\mathrm{I}} / \mathrm{T}_{\mathrm{TOT}}$ ) (7). An increase in $\mathrm{T}_{\mathrm{I}} / \mathrm{T}_{\text {TOT }}$ thus implies that the duration of expiration has decreased disproportionately in relation to the duration of inspiration. This may be caused by central nervous or peripheral reflex influences $(4,6,8)$. The respiratory "timing" as indicated by $\mathrm{T}_{\mathrm{I}} / \mathrm{T}_{\text {TOT }}$ increased approximately $45 \%$

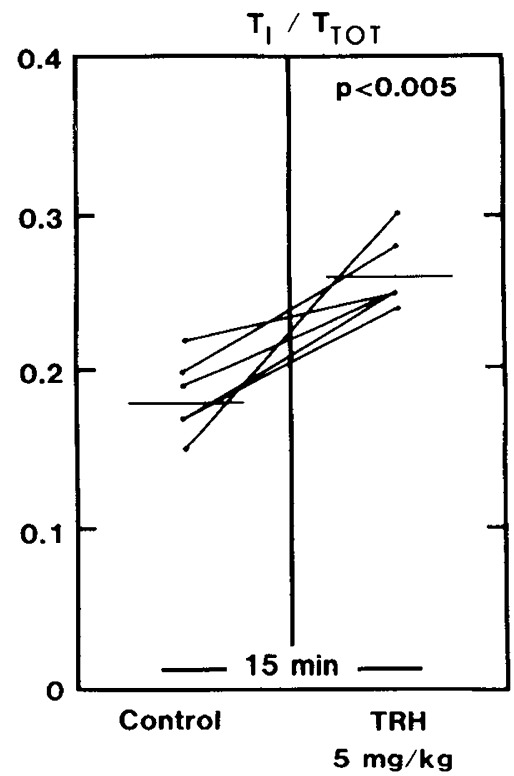

Fig. 7. "Inspiratory drive" ( $\left.\mathrm{V}_{\mathrm{T}} / \mathrm{T}_{\mathrm{l}}\right)$ and "respiratory timing" ( $\left.\mathrm{T}_{\mathrm{l}} / \mathrm{T}_{\text {TOT }}\right)$ before and after administration of $\mathrm{TRH}, 5 \mathrm{mg} / \mathrm{kg}$ intraperitoneally, to preterm rabbit neonates ( 29 days of gestational age).

RESPIRATORY FREQUENCY TIDAL VOLUME

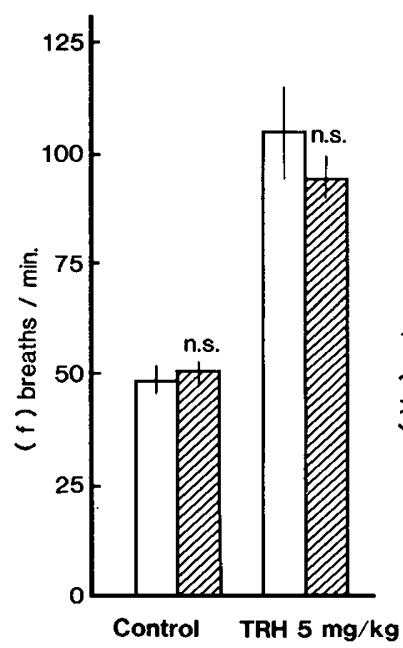

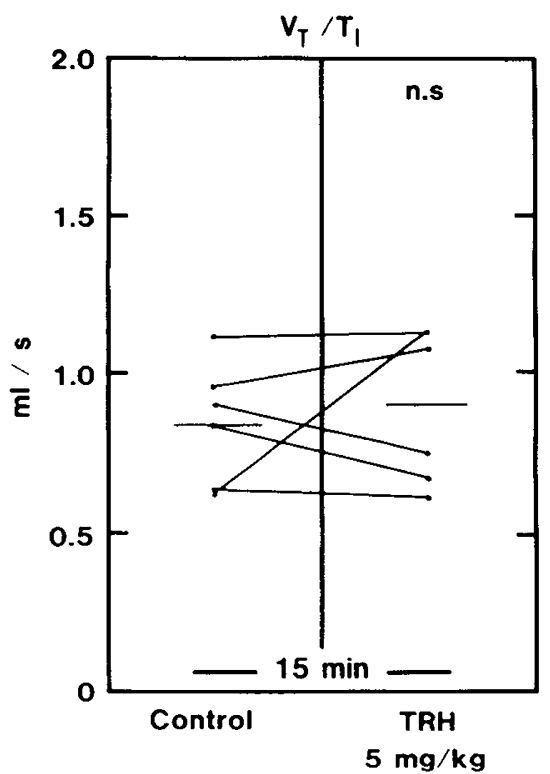

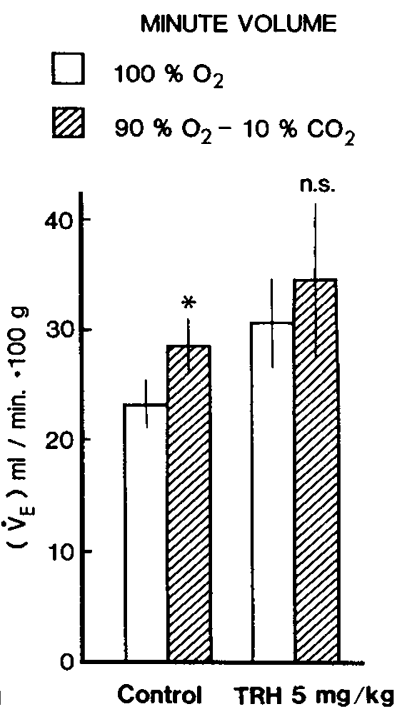

Fig. 8. Effects of TRH on resting and $\mathrm{CO}_{2}$ stimulated respiration in preterm rabbit neonates (29 days of gestational age). Two respiratory test periods were performed, one before and one $15 \mathrm{~min}$ after TRH administration. Included are all animals during control period and data from the animals given TRH $5 \mathrm{mg} / \mathrm{kg}$ intraperitoneally. Shown are means \pm s.e. for respiratory frequency (f), tidal volume $\left(V_{T}\right)$ and minute volume $\left(V_{E}\right)$. Statistics by paired $t$ test. ${ }^{*} P<0.05$. 
$15 \mathrm{~min}$ after TRH injection to the preterm rabbit neonates (Fig. 7). In order to get a further evaluation of the central respiratory drive in the newborn rabbits we have analysed $\mathrm{CO}_{2}$ induced changes on respiratory parameters. The $\mathrm{CO}_{2}$ sensing and responding mechanism is considered to be located in the reticular formation near the ventral surface of the medulla (1). The response to $\mathrm{CO}_{2}$ is also unaltered after denervation of the peripheral chemoreceptors (1). The addition of $10 \% \mathrm{CO}_{2}$ to the inhalational gas induced an increase in $\mathrm{V}_{\mathrm{T}}$ and $\dot{\mathrm{V}}_{\mathrm{E}}$ during the control registration (Fig. 8). An almost equal but nonsignificant trend for $V_{T}$ and $\dot{V}_{E}$ was seen after TRH.

\section{DISCUSSION}

Since the initial isolation of TRH from the hypothalamus (3, 21) it has become evident that this tripeptide is distributed throughout the extrahypothalamic central nervous system (CNS) and spinal cord $(2,16,24)$.

In the pituitary, TRH has a role in the tonic release of thyroid stimulating hormone. However, the major control of thyroid stimulating hormone secretion appears to be through direct feedback by thyroid hormones at the pituitary level (23). From immunohistochemical studies it can be estimated that only about one-third of the total CNS content of TRH may be found in the hypothalamus $(2,16,24)$. Also several lines of evidence suggest that extrahypothalamic regions possess the ability to synthesize TRH independent of any hypothalamic source (25). Thus, with regard to the distribution and physiologic effect of TRH in the CNS, it seems to be more relevant to look at this peptide as a neurotransmitter that has been co-opted by the pituitary as a releasing factor.

Immunohistochemical studies have revealed a high density of TRH immunofluorescent cell bodies and nerve terminals in "autonomic areas" relevant to central respiratory control in the brain stem region $(2,16,24)$.

A high dose of parenterally administered TRH will cause a number of effects in experimental animals, which are similar to those seen after intracerebroventricular administration (25).

We found that TRH administration to preterm neonatal rabbits caused a dose-dependent respiratory stimulation which was rapid in onset. The increase in minute volume was seen as a result of a marked increase in respiratory frequency. After TRH the total cycle duration $\left(T_{\text {TOT }}\right)$ was decreased. The shortening of $T_{\text {TOT }}$ was due to a marked decrease in $T_{E}$, whereas $T_{I}$ was only slightly reduced. Indeed, the increase in minute volume was due to the changes in respiratory timing mechanisms as evidenced by the increase in the $T_{I} / T_{\text {TOT }}$ "respiratory timing" ratio, mainly resulting from a relatively larger decrease in $\mathrm{T}_{\text {TOT }}$ (or $\mathrm{T}_{\mathrm{E}}$ ) compared to $T_{\mathrm{I}}$.

The slight reduction of $V_{T}$, which was seen after TRH, was probably secondary to the slight reduction in $T_{\mathrm{I}}$. The "inspiratory drive," indicated by the mean inspiratory flow $\left(V_{T} / T_{I}\right)$ was not significantly changed after TRH. This also indicates that TRH increases ventilation chiefly as a result of its effect on respiratory timing, i.e., $\mathrm{T}_{\mathrm{I}} / \mathrm{T}_{\text {Tот }}$.

The change in $T_{I} / T_{T O T}$ is most probably due to central nervous mechanisms and not peripheral reflex influences, as adiministration of TRH by the intracerebroventricular route to the rat stimulates respiration in the same manner (11). In microinjection studies in cats, TRH induces respiratory stimulation when injected into mesencephalic structures (20). Moreover, TRH also acts as a respiratory stimulant when administered to the primate (17).

In the untreated animals, $\mathrm{CO}_{2}$ stimulated minute ventilation mainly by an increase in tidal volume. After TRH no significant alterations were seen after $\mathrm{CO}_{2}$. It seems logical that TRH stimulates ventilation by mechanism unrelated to $\mathrm{CO}_{2}$ disposition. The mechanical changes after TRH, most likely causing a decrease in $\mathrm{PaCO}_{2}$ would then tentatively explain the lack of effect of the $\mathrm{CO}_{2}$ challenge after TRH. However, this could only be fully clarified by measuring arterial $\mathrm{CO}_{2}$ tensions, which was not performed during the present study.
During prenatal or early postnatal life, the CNS of most mammals is relatively immature. Thus many neuronal systems which are involved in central respiratory regulation such as catecholaminergic (15), serotoninergic, (14), gabaergic (5), and various peptidergic (22) systems may exhibit various degrees of maturity. Thus the net effect of respiratory "maturity" will depend on the relative balance between the maturation of respiratory stimulating and depressive systems. During a certain period of early postnatal age there may be a predominance of respiratory depressive input, which may serve as a base for irregular breathing and apnoic spells seen in the neonate. However, by identifying natural transmitters or transmitter analogues which act as respiratory stimulants, this balance may be changed. TRH seems to act in this way by stimulating respiratory activity also after intraperitoneal administration. Moreover, TRH acts neurotropic after intravenous, subcutaneous and oral administration (25). The rapid onset of action and relatively long duration (25) may further warrant the testing of TRH as a respiratory stimulant during the perinatal period.

\section{REFERENCES AND NOTES}

1. Berger, A. I., Mitchell, R. A., and Severinghaus, I. W.: Regulation of respiration (Part I-III). N. Engl. J. Med., 297: 92, 138, 194 (1977).

2. Brownstein, M. J., Palkovits, M., Saavedra, J. M., Bassiri, R. M. and Utiger, R. D.: Tyrotropin-releasing hormone in specific nuclei of rat brain. Science, 185: 267 (1974).

3. Burgus, R., Dunn, T. F., Desidero, D., Ward, D. N., Vale, W., and Guillemin, R.: Characterization of the hypothalamic hypophysiotropic TSH-releasing factor (TSF) of bovine origin. Nature 226: 321 (1970).

4. Clark, F. J. and von Euler, C.: On the regulation of depth and rate of breathing. J. Physiol. (Lond.), 222: 267 (1972).

5. Coyle, J. T. and Enna, S. J.: Neurochemical aspects of the ontogenesis of gabanergic neurons in the rat brain. Brain Res., 111: 119 (1976).

6. Gautier, H., Remmers, J. E., and Bartlett Jr. D.: Control of the duration of expiration. Respiration Physiol., 18: 205 (1973).

7. Goldberg, M.S. and Milic-Emili, J.: Effect of pentobarbital sodium on respiratory control in newborn rabbits. J. Appl. Physiol. Respirat. Environ. Exercise Physiol., 42: 845 (1977).

8. Grunstein, M. M., Younes, M., and Milic-Emili, J.: Control of tidal volume and respiratory frequency in anesthetized cats. J. Appl. Physiol., 35: 463 (1973).

9. Hedner, J., Jonason, J., and Lundberg, D.: Respiratory effects of gamma-hydroxybutyric acid in anesthetized rats. J. Neurol. Transm., 49: 179 (1980).

10. Hedner, J., Hedner, T., Bergman, B., and Lundberg, D.: Respiratory depression by GABA-ergic drugs in the preterm rabbit. J. Developm. Physiol., 2: 401 (1980).

11. Hedner, J., Hedner, T., Jonason, J., and Lundberg, D.: Central respiratory stimulant effect of TRH in the rat. Neurosci. Lett., 25: 317 (1981)

12. Hedner, T., Hedner, J., Bergman, B., and Lundberg, D.: Transient apnoea after an enkephalin analogue in the preterm rabbit. Biol. Neonate., 39: 290 (1981)

13. Hedner, T., Hedner, J., Jonason, J., and Lundberg, D.: Evidence suggesting a role of Substance $P$ in central respiratory regulation in the rat. Acta Physiol. Scand., 112: 487 (1981)

14. Hedner, T. and Lundborg, P.: Serotoninergic development in the postnatal rat brain. J. Neural. Transm., 49: 257 (1980).

15. Hedner, T. and Lundberg, P.: Neurochemical characteristics of cerebral catecholamine neurons during the postnatal development in the rat. Medical Biol., 59: 212 (1981).

16. Jackson, I. M. D. and Reichlin, S.: Tyrotropin-releasing hormone (TRH): distribution in hypothalamic and extrahypothalamic brain tissues of mammalian and submammalian chordates. Endocrinology 95: 854 (1974).

17. Kraemer, G. W., Mueller, R., Breese, G. R., Prange, A. J., Lewis, J. K., Morrison, H., and McKinney, W. T.: Tyrotropin-releasing hormone: antagonism of pentobarbital narcosis in the monkey. Pharmac. Biochem. Behav., 4: 709 (1976).

18. Lundberg, D., Breese, G. R., and Mueller, R. A.: Dopaminergic interaction with the respiratory control system in the rat. European J. Pharmacol., 54: 153 (1979).

19. Mueller, R. A., Lundberg, D., and Breese, G. R.: Evidence that respiratory depression by serotonin agonists may be exerted in the central nervous system. Pharmacol. Biochem. Behav. 13: 247 (1980).

20. Myers, R. D., Metcalf, G., and Rice, J. C.: Identification by microinjection of TRH-sensitive sites in the cat's brain stem that mediate respiratory, temperature and other autonomic changes. Brain Res., 126: 105 (1977).

21. Nair, R. M. G., Barrett, J. F., Bowers, C. Y., and Schally, A. V.; Structure of porcine thyrotropin releasing hormone. Biochemistry, 9: 1103 (1970).

22. Patey, G., de la Baume, S., Gros, C., and Schwartz, J-C.: Ontogenesis of enkephalinergic systems in rat brain: Postnatal changes in enkephalin levels, receptors and degrading enzyme activities. Life Sci., 27: 245 (1980).

23. Reichlin, S. and Mitnick, M. A.: Biosynthesis of tyrotropin-releasing hormone and its control by hormones, central monoamines and external environment. In: Hypothalamic, Hypophysiotropic Hormones. Excerpta Med. Int. Congr. Ser., 263: 124 (1973). 
24. Winokur, A. and Utiger, R. D.: Thyrotropin-releasing hormone: regional distribution in rat brain. Science, 185: 265 (1974)

25. Yarbrough, G. G.: On the neuropharmacology of tyrotropin releasing hormone (TRH). Progr. in Neurobiology, 12: 291 (1979).

26. The technical assistance by Gabriella Salén and Kristina Kårmark is gratefully acknowledged.

27. Requests for reprints should be addressed to: Thomas Hedner, M.D., Department of Pharmacology, University of Göteborg, Box 33031, S-400 33 Göteborg, Sweden.

28. This research was supported by the Swedish Medical Research Council (grants 2464 and 2862), the Swedish National Association against Heart and Chest Diseases, Expressens Prenatalforskningsfond and Allmänna BB's minnesfond. 29. Received for publication July 14, 1981 .

30. Accepted for publication November 20, 1981.

Copyright $(\mathcal{C} 1982$ International Pediatric Research Foundation, Inc.

Printed in U.S.A. $0031-3998 / 82 / 1606-0543 \$ 0.200 / 0$ 